\title{
THE EFFECT OF RETURN ON EQUITY, DIVIDEND YIELD, PRICE EARNING RATIO, EARNING PER SHARE, AND FIRM SIZE ON STOCK RETURN ON LQ45 SHARES IN INDONESIA STOCK EXCHANGE
}

\author{
Gilang Caesar Yudhan Shia ${ }^{a}$, Yanuar Dananjaya ${ }^{\text {b }}$, Cicilia Erna Susilawati ${ }^{\mathrm{c} *}$ \\ ayudhanshia@gmail.com \\ ${ }^{a}$ Master of Management Student at Pelita Harapan University, Ahmad Yani Road number 288, Surabaya 60234, Indonesia \\ ${ }_{b, c}$ The Lecturer of Master of Management at Pelita Harapan University, Ahmad Yani Road number 288, Surabaya 60234, Indonesia
}

\begin{abstract}
One investment that can be used as an investment tool is shares in the Indonesian capital market. In investing in the capital market, it is necessary for investors to analyze the company, one of the ways is by fundamental analysis, so that investors understand the company's future prospects. One of the indices in the Indonesian capital market that investors can refer to is the LQ45 Index. The LQ45 Index is an index that measures the price performance of 45 stocks that have high liquidity and large market capitalization and are supported by good fundamental companies.This study aims to analyze the effect of Return on Equity, Dividend Yield, Price Earning Ratio, Earning per Share, and Firm Size on Stock Return on LQ45 stocks. Companies that are the research sample must meet the following criteria: Non-banking companies listed on the IDX, non-banking companies actively trading their shares in the 2014-2018 period, companies that have positive net income (NI), companies that have a dividend yield "0", companies that have a Stock Return value below $+-100 \%$. This study uses quantitative methods and data processing using SPSS with cross section data.The results showed that there are two variables accepted : Price Earning Ratio has a negative and significant effect on Stock Return with a standardized coefficients beta of 0.215 and a $t$ sig value of 0.013; Firm Size has a positive and significant effect on Stock Return with a standardized coefficients beta value of -0.213 and a t sig value of 0.006 , and 3 variables are rejected : Return on Equity has a positive but not significant effect on Stock Return with a standardized coefficients beta value of 0.003 and a $t$ sig value of 0.969 ; Dividend Yield has a positive but not significant effect on Stock Return with a standardized coefficients beta value of 0.038 and a t sig value of 0.626; Earning per Share has a positive but insignificant effect on Stock Return with a standardized coefficients beta of 0.003 and a t sig value of 0.970 .
\end{abstract}

Keywords: Return on Equity, Dividend Yield, Price Earning Ratio, Earning per Share, Firm Size, Stock Return

\section{Background}

In living life, many things will come in the life of each individual such as work, school, marriage, vacation, buying a car / motorbike, a house for the newlyweds and equipment and necessities of daily life. Our initial needs are such as going to school, the cost of entering school from elementary school to college is not small, reported from cnbcindonesia.com that for school to college can reach approximately 142 million. therefore it is necessary to cover it with investment. According to Tandelilin (2010), investment is a commitment to a lot of money that is being carried out, with the hope of obtaining many benefits in the future. Investment itself can be associated with various activities. Investing large amounts of money can be in real estate such as land, machinery or buildings, and financial assets contained in financial instruments in the capital market, such as stocks, bonds, mutual funds, and other instruments. In investing, we also have to determine the investment time we want, such as the short term $(<1$ year), medium term (1-5 years) or long term ( $>5$ years). Investing in addition to determining the investment time, we must also determine the benefits we want to get and the investment objectives. This needs to be applied in investment because each investment instrument has a different function, for example if we want to renovate a house within the next 1 year then we can consider using a deposit investment instrument (https://www.simulasikredit.com, downloaded on 23 May 2020).

One of the investments that has a high return is stocks. Shares themselves can be interpreted as securities which prove that investors have participated in the ownership of the company. When an investor buys shares, the investor is obliged to provide money based on the total share price when he wants to buy the shares, and every time he buys shares, the investor must pay a transaction fee charged by the securities company. When selling shares, the total funds that investors will receive is the value based on the selling price of the shares, minus transaction costs and income tax. In stocks, there are two advantages that investors can get if they invest in stocks, namely Capital Gain and Dividends. Capital gain is the profit obtained when the price rises and

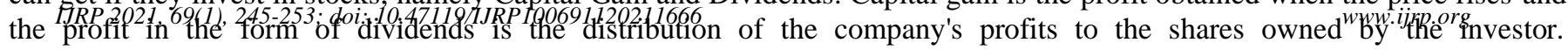
(https://www.sahamok.com, downloaded on 23 May 2020). 
shares in companies listed on the LQ45 index. The LQ45 index is a combination of 45 companies selected through several selection criteria, one of those is liquidity. This stock selection also considers market value. Apart from considering liquidity standards and market value, the company's financial status and growth prospects will also be considered. The LQ 45 index consists of 45 companies selected every six months (in February and early August). So that the companies in LQ45 are not always the same. The existence of this index is also a means for investors, fund managers, and financial analysts to monitor changes in the price of traded shares (http://www.juruscuan.com, downloaded on May 24, 2020).

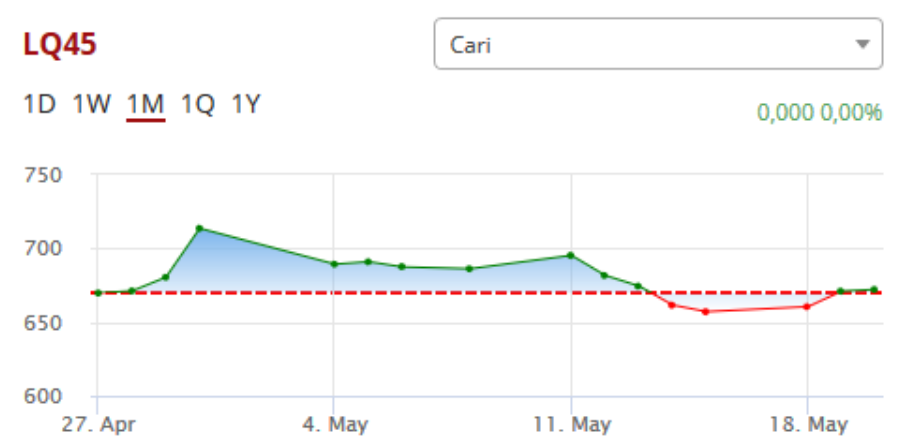

Figure 1.1 LQ45 Index April-May 2020

Source: https://www.idx.co.id/

Figure 1.1, the index on LQ45 in the past April-May 2020, namely April-May, also has the same thing as the composite stock price index (IHSG), which has experienced rising and falling prices. Shares that are in LQ45 (February-July 2020 period) consist of: ACES, ADRO, AKRA, ANTM, ASII, BBCA, BBNI, BBRI, BBTN, BMRI, BRPT, BSDE, BTPS, CPIN, CTRA, ERAA, EXCL, GGRM , HMSP, ICBP, INCO, INDF, INKP, INTP, ITMG, JPFA, JSMR, KLBF, LPPF, MNCN, PGAS, PTBA, PTPP, PWON, SCMA, SMGR, SRIL, TBIG, TLKM, TKIM, TOWR, UNTR, UNVR , WIKA, WSKT (https://www.seputarforex.com, downloaded on 24 May 2020). In investing, of course, investors want to have a good or high return. In addition, investors certainly don't want to make the wrong investment in shares in the company. To obtain capital gains in stocks, investors can use technical analysis as well as fundamental analysis. In fundamental analysis to obtain returns, investors can use Return on Equity, Dividend Yield, Price Earning Ratio, Earning per Share, Debt to Equity Ratio or other ratio analysis.

Fundamental analysis according to Artha et al (2014) is a study of the economy, industry and company conditions to calculate share value. Fundamental analysis looks at the company's financial statements to determine if the stock price has appreciated correctly. In stock investing, if the investor does not carry out the analysis, the investor cannot predict changes in stock prices at any time. The most suitable stock price analysis is fundamental analysis, because by using fundamental analysis, investors can consider the risks and stock prices that have or are currently happening. Fundamental analysis can consider the risks and rewards that can be received in the form of dividends or capital gains. In fundamental analysis, investors can also find out the valuation of their shares, namely how much the value of the shares is worth paying for.

The research gap shows the relationship between Earning per Share and Stock Return. Previous research has found that the positive and significant effect of Earning Per Share on Stock Return (Wahyuni et al. 2013; Wang 2012; Emamgholipour et al. 2013; Mirfakhr et al. (2011). However, it has differences with research conducted by Rumokoy \& Tanumu (2015) where Earning per Share to Stock Return has a positive but not significant. This is because companies that have high Earning per Share are not consistent with having a large Stock Return. This gap will create a gap for further exploration to be carried out for obtain theoretical and practical concepts about the relationship between variables Earning per Share and Stock Return.

The second research gap shows the relationship between Firm Size and Stock Return. Previous research found that Firm Size and Stock Return has a positive and significant (Ismanto 2011; Sugiarto 2011; Purwaningrat \& Suaryana 2015. However, it has a difference with research conducted by Abdullahi (2011) where the influence Firm Size on Stock Return has a negative effect. This is because in the research conducted by Abdullahi et al (2011) that investment in large companies such as blue chip does not necessarily guarantee investment security in the capital market and also does not ensure high returns over time. The existence of this gap will create a gap for further exploration to obtain theoretical and practical concepts regarding the relationship between Firm Size and Stock Return variables.

The third research gap shows the relationship between Price Earning Ratio and Stock Return. Previous research has shown a positive and significant effect of Price Earning Ratio on Stock Return (Karami et al. 2013; Harsalim 2013; Purba et al. 2017). This is because investors use PER as an analytical tool to obtain a fairly large return on stock investment. Investors believe that the higher the $\mathrm{P} / \mathrm{E}$ ratio, the better the price in each stock market, so that investors can get returns from changes in stock prices. However, there is a gap with research conducted by Emamgholipour et al (2013) where the effect of Płicue Ërrnirng Ratio on Stock Return has a negative and significant. With this gap, it will create a gap for further exploration to obtain theoretical and practical concepts about the relationship between Price Earning Ratio and Stock Return variables. 


\section{Literature Review}

\subsection{Return on Equity}

According to Animah (2010), Return on Equity (ROE) is one of the ratios used by investors to evaluate a company. Return on Equity shows the company's ability to get profit that can be used by its shareholders. The greater the Return on Equity, the greater the profit. Kijewska (2016) defines Return on Equity is an important measure of a company's revenue performance. ROE tells general shareholders how effectively investors' money is being used. Therefore, investors can determine whether a company can create profits or not be able to make a profit from the money that investors invest in these stocks and also how efficient management is in creating profits. Return on Equity is a reflection of the company's ability to provide income to investors by showing the percentage of net income that the company has used for capital from investors (Aisah \& Mandala, 2016). Therefore, we predict the Return on Equity has a significant effect on Stock Return. This leads to the hypotheses as the following:

Hypothesis 1: Return on Equity has a positive and significant effect on Stock Return

\subsection{Dividend Yield}

According to Purnamasari (2013), Dividend Yield is a profit distributed to investors based on the number of shares they own. According to Hirt (2006), Dividend Yield is the percentage of profit per share divided by the market price per share received by the company. A high dividend yield indicates undervalued, that is, if the share price is lower than its fair value, then you must buy and hold the stock temporarily (buy and hold) to obtain capital gains when the price then rises. The dividend yield prediction comes from the role of dividend policy in distributing the return earned by the company to shareholders. Hanafi \& Halim (2009) defines Dividend Yield is a part of the total income earned by investors. Another part of the return is the capital gain obtained from the positive difference between the selling price and the buying price. If there is a negative difference, there is a capital loss. Generally, companies with high growth prospects have low dividend yields because most of the dividends will be reinvested. According to Warsono (2002), Dividend Yield is a comparison between the amount of dividends paid by a company and the market price of its shares. Dividend Yield calculation shows the amount of return received by investors from dividends distributed by the company. Therefore, we predict the Dividend Yield has a significant effect on Stock Return. This leads to the hypotheses as the following:

\section{Hypothesis 2: Dividend Yield has a positive and significant effect on Stock Return}

\subsection{Price Earning Ratio}

According to Putra (2018), the $\mathrm{P} / \mathrm{E}$ ratio is the share price divided by earnings per share. The $\mathrm{P} / \mathrm{E}$ ratio calculates the company's profitability. The results show that how many investors are willing to pay per rupiah for company revenue. The higher the $\mathrm{P} / \mathrm{E}$, the higher the prospect of share price for earnings per share, therefore the higher the $\mathrm{P} / \mathrm{E}$ ratio also indicates that the shares are relatively more expensive than earnings per share (Arslan et al, 2014). Companies with high growth expectations (with good prospects) have high $\mathrm{P} / \mathrm{E}$ ratios, while companies (companies with bad prospects) have lower $\mathrm{P} / \mathrm{E}$ ratios (Marisa \& Lestari, 2017). Price Earning Ratio according to Emamgholipour et al. (2013) is another ratio from the market that shows the willingness of investors to buy company shares in cash according to reported earnings. The increase in Price Earning Ratio shows the satisfactory development of the company in the eyes of investors. Masruri (2016), Price Earning Ratio is the ratio between stock prices and net income. The $\mathrm{P} / \mathrm{E}$ ratio value represents several times the market price. For example, the $\mathrm{P} / \mathrm{E}$ ratio $=15$ means that the stock market price is 15 times the EPS. Thus, the greater the $\mathrm{P} / \mathrm{E}$, the more expensive the share price is, and the lower the earnings per share compared to the price. Price Earning Ratio is a method for determining the true value of a company's shares. Therefore, we predict the Price Earning Ratio has a negative and significant effect on Stock Return. This leads to the hypotheses as the following:

\section{Hypothesis 3: Price Earning Ratio has a negative and significant effect on Stock Return}

\subsection{Earning per Share}

According to Putra (2018) Earning per Share is the net profit per share that will be received by these shareholders. Earning per Share (Jasman \& Kasran, 2017) is a ratio that shows the net income for each share for shareholders. A higher ratio will be well assessed by investors. Therefore, the tendency of potential investors to invest in companies with high earnings per share will also increase. Ultimately, it will increase returns for shareholders. Likewise, if the earnings per share ratio is low, potential investors will see the information content. According to Tandelilin (2010) Earning per Share is to show the company's net profit that is ready to be distributed to all investors. Since earnings per share have a direct impact on investors, a large amount of earnings per share means large payments to investors, whereas a small amount per share means small payments to investors. According to Hery (2015), Earning per Share is a measure of the success rate of company management in providing profits to investors who own shares. EPS shows the relationship between the amount of net income and the share of shareholders' equity in the company. New investors can use EPS to make decisions among existing ratios. Earning per share is the level of earnings per share that a company can achieve when running a business. Earnings per share is calculated by dividing the profit available to ordinary shareholders by the average number of ordinary shares issued (Indah \& Parlia, 2017). Therefore, we predict the Earning per Share has a significant effect on Stock Return. This leads to the hypotheses as the following: 


\section{5 $\quad$ Firm Size}

According to Rahmawati (2015) Firm Size can be categorized into three groups, namely large-scale companies, mediumscale companies, and small-scale companies. There are various steps used to determine company size. For example, total assets, sales, and market capitalization and many other actions that can affect investors' judgment in making investments. Firm Size is how big a company is. Based on the Firm Size, companies are divided into big companies and small companies. So Firm Size is the market value (market value) of a company. Market value can be obtained by calculating the stock market price multiplied by the number of shares issued (Aisah \& Mandala, 2016). Nurbaety (2014) states that the size of a company can determine how easily the company can get from investors. Small companies often lack access to investors' markets. Even if the company has access rights, the initial costs of selling securities in small amounts can be a constraint. If the issuance of securities is possible, then the securities of small companies may not be marketable and therefore need to be priced in a way that will allow the investor to earn significantly higher returns. Therefore, we predict the Firm Size has a significant effect on Stock Return. This leads to the hypotheses as the following:

\section{Hypothesis 5: Firm Size has a positive and significant effect on Stock Return}

\subsection{Stock Return}

Stock Return according to Tandelilin (2010) Stock Return is one of the factors that encourages investors to invest and get reward for the amount of money invested by bearing the risk. Legiman et al (2015) state that Stock Return is the result obtained by investors when investors invest in a stock. Stock Return can be positive or negative, if a positive number means getting a profit or obtaining capital gains while a negative number means a loss or obtaining capital loss. According to Suciati (2018) Stock Return is the return of shares or the level of profit is the profit obtained from investing in a company either directly or through a securities company.

\section{Research Methods}

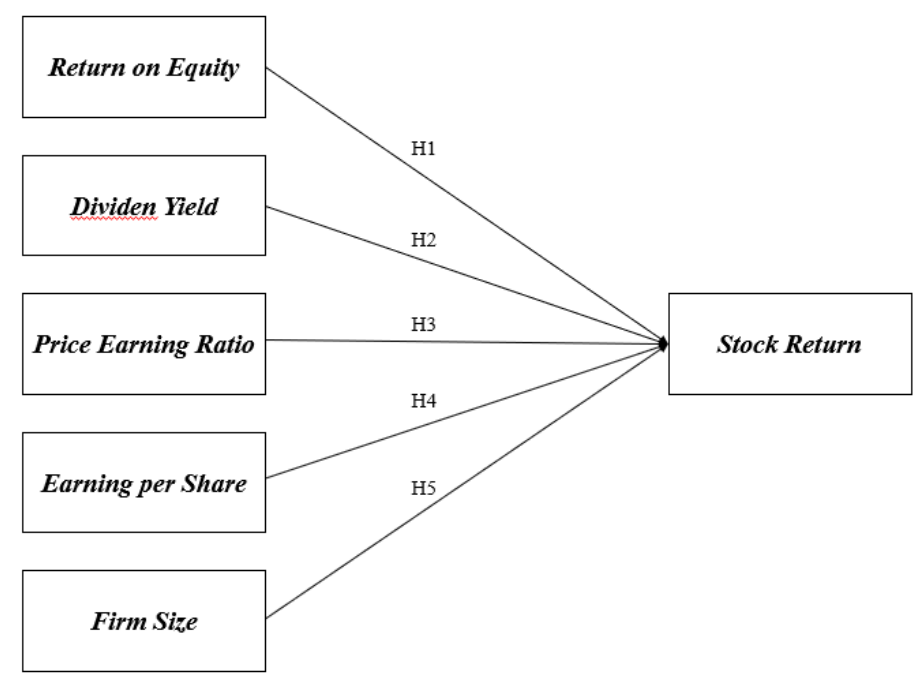

\section{Figure 3.1 Research Model}

The method used in the study was quantitative. The population in this research are securities companies which shares are listed on the Indonesia Stock Exchange (BEI). The Indonesia Stock Exchange (IDX) was chosen as the object of observation because the Indonesia Stock Exchange (IDX) was the reference for carrying out all capital market activities in Indonesia. The sampling technique used is non-probability sampling because it does not provide equal opportunities for every element or member of the population selected as the sample. Certain considerations for determining the research sample was non-banking companies registered in LQ45 in a certain year between 2014 and 2018, which amounted to 45 companies updated every six months. According to the specified standards, the number of samples in this study was 199 . which amounted to 45 companies updated every six months. After the data is tabulated, then the research model will be tested using IBM SPSS software version 22.0. This research just used one regression which is to measure the effect of independent variables on Stock Return Variable, which shows the results of the hypothesis 1-5. The dependent variable in this study is Stock Return using annual Excess Return as a proxy for Stock Return. This sample uses a list from the period February to July. The companies that are sampled must pass the following criteria: Non-banking companies listed on the IDX, Non-banking companies actively trading their shares in the 2014-2018 period, Companies that have positive Net Income (NI), Companies that have a dividend yield is not worth " 0 ", Companies that have an Excess Return value above $+-100 \%$. 


\section{Results and Discussion}

Table 4.1 The total sample of companies that pass the criteria

\begin{tabular}{|c|c|}
\hline non-banking stocks 2014-2018 & $\mathbf{1 9 9}$ \\
\hline Excess Return value above $+-100 \%$ & $(8)$ \\
\hline Net income negative & $(6)$ \\
\hline Dividend Yield is "0" & $(21)$ \\
\hline The number of samples used & $\mathbf{1 6 4}$ \\
\hline
\end{tabular}

Table 4.1 shows the number of samples that have passed the criteria. then the total sample used is 164 non-banking companies registered from 199 samples registered in the LQ45 index in 2014-2018. Therefore this study used 164 samples.

Table 4.2 The regression analysis

\begin{tabular}{|c|c|c|c|c|c|}
\hline Model / Variabel & Adj R & $\mathbf{F}_{\text {sig }}$ & $\begin{array}{c}\text { Standardized Coefficients } \\
\text { Beta }\end{array}$ & $\mathbf{t}_{\text {sig }}$ & Hipotesis \\
\hline & 0,071 & 0,005 & & & \\
\hline Return on Equity & & & 0,003 & 0,969 & Rejected \\
\hline Dividend Yield & & & 0,038 & 0,626 & Rejected \\
\hline Price Earning Ratio & & & $-0,213$ & 0,006 & Accepted \\
\hline Earning per Share & & & 0,003 & 0,970 & Rejected \\
\hline Firm Size & & & 0,215 & 0,013 & Accepted \\
\hline
\end{tabular}

Based on table 4.2, the following regression equation can be generated:

\section{$Y=0,003 . X 1+0,038 X 2-0,213 . X 3+0,003 . X 4+0,215 . X 5$}

Where:

$\mathrm{Y}=$ Excess Return

$\mathrm{X} 1=$ Return on Equity

$\mathrm{X} 2$ = Dividend Yield

X3 = Price Earning Ratio

$\mathrm{X} 4$ = Earning per Share

X5= Firm Size

Based on table 4.2, the Adjusted R2 figure is 0.071 or $7.1 \%$, indicating that the percentage contribution of the effect of Return on Equity, Dividend Yield, Price Earning Ratio, Earning per Share, Firm Size to Stock Return is 7.1\% which means that the effect of Return on Equity, Dividend Yield, Price Earning Ratio, Earning per Share, Firm Size can explain 7.1\% Excess Return, while the remaining $92.9 \%$ is influenced by other variables not included in this research model. The results of the F test show a significance value of 0.005 , this means that the research model which aims to examine the effect of Return on Equity, Dividend Yield, Price Earning Ratio, Earning per Share, Firm Size on Excess Return can be accepted so that it can be concluded together that the effect of Return on Equity, Dividend Yield, Price Earning Ratio, Earning per Share, Firm Size can affect Excess Return as proxy for Stock Return.

Based on table 4.2, the number $\mathrm{t}$ sig is obtained. The $\mathrm{t}$ test is used to determine the influence of the independent variables partially on the dependent variable. The $t$ test result with a significance value $<0.05$ indicates that the hypothesis is accepted, whereas if $>0.05$ indicates that the hypothesis is rejected. From the results that have been done, it can be concluded that: 
Table 4.3 Summary of Testing Results

$\mathrm{s}$

\begin{tabular}{|l|c|}
\hline \multicolumn{1}{|c|}{ Hypothesis } & Analysis \\
\hline H1: Return on Equity has a positive and significant effect on Stock Return & Rejected \\
\hline H2: Dividend Yield has a positive and significant effect on Stock Return & Rejected \\
\hline H3: Price Earning Ratio has a negative and significant effect on Stock Return & Accepted \\
\hline H4: Earning per Share has a positive and significant effect on Stock Return & Rejected \\
\hline H5: Firm Size has a positive and significant effect on Stock Return & Accepted \\
\hline
\end{tabular}

Source: IBM SPSS 22.0 Analysis Result, 2020

\subsection{Effect of Return on Equity on Stock Return (H1)}

The results of the research for the first hypothesis state that Return on Equity has a positive but not significant effect on Stock Return. The results of this study are in line with previous research conducted by Aisah \& Mandala (2016) which states that Return on Equity has a positive but not significant effect on Stock Return. This result indicates that the large or small value of the Return on Equity depends on whether the profit from the company increases or the equity of the company decreases. Thus, the low or high value of Return on Equity does not affect investors in making decisions to invest in a company because no matter how good the company is, if the company is able to manage the existing or minimal equity, the company can generate profits with existing equity. Return on Equity could increase because the company's performance increased (positive), it could be because the level of debt increased (negative). Therefore in total it has no effect on stock returns. In addition, it could also be that the majority of investors do not pay attention to current conditions of profitability or Return on Equity to estimate returns because the majority of investors see the potential of a stock in the future to develop even though the stock is currently experiencing a loss.

\subsection{Effect of Dividend Yield on Stock Return (H2)}

The results of the research for the second hypothesis state that Dividend Yield has a positive but not significant effect on Stock Return. The results of this study are in line with previous research conducted by Kurniasih Andriana (2011) that Dividend Yield has a positive but not significant effect on Stock Return. This is because the majority of Indonesian investors in investing may prefer to get capital gains rather than getting high dividends. According to Brigham \& Houston (2009), basically, the dividend determines how much profit will be distributed to shareholders and also how much of the profit is withheld for investment by the company to get more profit. So in this case that the more money that is retained to develop the company's business, it will be able to increase the company's profits. An increase in profits or profits from the company signals to investors that the company can produce an increase in profits from year to year or in experiencing growth so that later it will increase the Stock Return of the company, which means that the capital gains obtained by investors will also be large. In this case, it means that Indonesian investors do not pay too much attention to the high dividend yield as a factor in determining investment.

\subsection{The Effect of Price Earning Ratio on Stock Return (H3)}

The results of the research for the third hypothesis state that Price Earning Ratio has a negative significant effect on Stock Return. The results of this study are in line with previous research conducted by Emamgholipour et al. (2013) that Price Earning Ratio has a negative significant effect on Stock Return. This is because investors prefer or choose a low Price Earning Ratio value because the stock is still classified as cheap to buy in the present so that it is hoped that in the future the price will rise with an increase in price, so the return of the company will increase or be high. According to Arslan et al (2014), a low Price Earning Ratio indicates that a company's stock price has a lower intrinsic (undervalued) market price and thus attracts investors to make investment choices due to its low price. In this case, the Price Earning Ratio is one of the factors in determining long-term investment

\subsection{Effect of Earning per Share on Stock Return (H4)}

The results of the research for the fourth hypothesis state that Earning per Share has a positive but not significant effect on Stock Return. The results of this study are in line with previous research conducted by Tamunu \& Rumokoy (2015) that Earning per Share has positive but not significant effect on Stock Return. This is because investors are not necessarily able to predict the Stock Return of companies that have large Earning per Share or experience an increase in Earning per Share because these companies are not necessarily consistent in owning or producing large Stock Returns. Earning per Share does not indicate an expensive or cheap stock. A large earning per share when the stock price is high does not mean it is a good stock for investment.

\subsection{Effect of Firm Size on Stock Return (H5)}

The results of the research for the fifth hypothesis state that Firm Size has a positive significant effect on Stock Return. The results of this study are in line with previous research conducted by Acheampong et al. (2014) that Firm Size has positive significant effect on Stock Return. This is because according to Prasetyorini (2013) a large Firm Sizerindifgaters that the company already has expertise or can face change so that it can be said that the company is more stable. In addition, a high Firm Size has a very small bankruptcy rate because the company always has a high profit rate or increases every year so that this makes the trust of investors increase, with the trust of investors it will bring interest from these investors to invest in the company. which leads to an increase in the stock price and an increase in the company's Stock Return. 


\section{Conclusion}

Based on the results of the study, the 5 independent variables used in the research model were 2 independent variables that had a significant effect on the dependent variable and 3 independent variables that had no significant effect on the dependent variable. The results of the analysis and hypothesis testing are as follows:

- Return on Equity has a positive but insignificant effect on the Stock Return of non-banking companies listed in LQ45 in the annual calculation for the 2014-2018 period. In this research, it can be said that the Return on Equity is not used as a reference by investors to make investments.

- Dividend Yield has a positive but insignificant effect on the Stock Return of non-banking companies listed in LQ45 in the annual calculation for the 2014-2018 period. In this research, it can be said that the Dividend Yield is not used as a reference by investors to make investments

- Price Earning Ratio has a negative but significant effect on the Stock Return of non-banking companies listed in LQ45 in the annual calculation for the 2014-2018 period. In this research, it can be said that the Price Earning Ratio can be used as a reference for investors to make investments.

- Earning per Share has a positive but insignificant effect on the Stock Return of non-banking companies listed in LQ45 in the annual calculation for the 2014-2018 period. In this research, it can be said that Earning per Share is not used as a reference by investors to make investments.

- Firm Size has a positive but significant effect on the Stock Return of non-banking companies listed in LQ45 in the annual calculation for the 2014-2018 period. In this study, it can be said that the Firm Size can be used as a reference for investors to make investments.

\section{Recommendations}

There are several recommendations that can be given so that further research can be more comprehensive. The following are some recommendations that can be given, namely:

- In this study, the observation period was short, 5 years from 2014-2018. Future research is expected to extend the span of observation time so that the number of research samples is also more.

- Further researchers are expected to use other dependent variables such as Price Earning Ratio.

- The next researcher is expected to use the quarterly method in order to see that the variables Return on Equity, Dividend Yield, Price Earning Ratio, Earning per Share, Firm Size can apply when predicting Stock Return in shortterm investing.

- The research is only limited to LQ45, so it is hoped that in further research, object selection should use other indexes such as Kompas 100 or the Indonesian Sharia Stock Index (ISSI).

\section{References}

Acheampong, P., Agalega, E., \& Shibu, A. K. (2014). The effect of financial leverage and market size on stock returns on the Ghana Stock Exchange: evidence from selected stocks in the manufacturing sector. International Journal of Financial Research, 5(1), 125.

Aisah, A. N., \& Mandala, K. (2016). Pengaruh Return On Equity, Earning Per Share, Firm Size dan Operating Cash Flow Terhadap Return Saham. E-Jurnal Manajemen Universitas Udayana, 5(11).

Animah, A. (2010). Pengaruh Price Earning Ratio, Price To Book Value Ratio, Debt to Equity Ratio, Return on Equity dan Size terhadap Return Saham Pada Periode Bullish (Survei PadaPerusahaan Manufaktur di Bursa Efek Indonesia Periode 2006-2007). JURNAL AKUNTANSI UNIVERSITAS JEMBER, 8(1).

Arslan, M., Zaman, R., \& Phil, M. (2014). Impact of dividend yield and price earnings ratio on stock returns: A study of non-financial listed firms of Pakistan. Research Journal of Finance and Accounting, 5(19), 68-74.

Brigham, E. F., \& Houston, J. (2009). Fundamentals of financial management (concise 6th ed.).

Emamgholipour, M., Pouraghajan, A., Tabari, N. A. Y., Haghparast, M., \& Shirsavar, A. A. A. (2013). The effects of performance evaluation market ratios on the stock return: Evidence from the Tehran stock exchange. International Research Journal of Applied and Basic Sciences, 4(3), 696-703. 
Emamgholipour, M., Pouraghajan, A., Tabari, N. A. Y., Haghparast, M., \& Shirsavar, A. A. A. (2013). The effects of performance evaluation market ratios on the stock return: Evidence from the Tehran stock exchange. International Research Journal of Applied and Basic Sciences, 4(3), 696-703.

Hanafi dan Halim. (2009). Analisis Laporan Keuangan. Edisi keempat.

Hery. (2015). Analisis Laporan Keuangan Pendekatan Rasio Keuangan. Yogyakarta: CAPS (Center for Academic Publishing Service).

Hirt, B. (2006). Fundamental of Investment Management, $8^{\text {th }}$ edisi. Mc Graw Hill International Edition.

Indah, D. R., \& Parlia, P. (2017). Pengaruh Earning Per Share Terhadap Harga Saham Pada PT. Bank Mega Tbk. Jurnal Penelitian Ekonomi Akuntansi (JENSI), 1(1), 72-81.

Jasman, J., \& Kasran, M. (2017). Profitability, Earnings Per Share on Stock Return with Size as Moderation. Trikonomika, 16(2), 88-94.

Kijewska, A. (2016). Determinants of the return on equity ratio (ROE) on the example of companies from metallurgy and mining sector in Poland. Metalurgija, 55(2), 285-288.

Kurniasih, N., Andriana, S. (2011). Pengaruh dividend yield dan price earning ratio (PER) terhadap return saham pada level investment opportunity set (OPS) yang berbeda (study pada saham LQ45 yang tercatat di BEI). Jurnal Ekonomi Sosial 7(1): 38-45.

Legiman, F. M., Tommy, P., \& Untu, V. (2015). Faktor-faktor yang mempengaruhi return saham pada perusahaan agroindustry yang terdaftar di Bursa Efek Indonesia periode 2009-2012. Jurnal EMBA: Jurnal Riset Ekonomi, Manajemen, Bisnis dan Akuntansi, 3(3).

Marisa, S., Situmorang, M., \& Lestari, M. E. (2017). Pengaruh Earning Per Share dan Price Earning Ratio terhadap Harga Saham Pada Perusahaan Food and Beverage yang Terdaftar di Bei Periode 2011-2015. Jurnal Online Mahasiswa (JOM) Bidang Akuntansi, 2(2).

Masruri, M. (2012). Pengaruh Price Earning Ratio, Return on Equity dan Debt to Equity Ratio terhadap Return Saham Sektor Jasa Keuangan di Bursa Eefek Indonesia Periode Tahun 2008-2010. Vol. 5 No, 1.

Nurbaety, L. (2014). Pengaruh Persistensi Laba, Kesempatan Bertumbuh Dan Ukuran Perusahaan Terhadap Earnings Response Coefficient (Studi Empiris Pada Perusahaan Pertambangan Yang Terdaftar Di Bursa Efek Indonesia Tahun 2008-2012) (Doctoral Dissertation, Fakultas Ekonomi Unpas).

Prasetyorini, B. F. (2013). Pengaruh ukuran perusahaan, leverage, price earning ratio dan profitabilitas terhadap nilai perusahaan. Jurnal Ilmu Manajemen, 1(1), 183-196.

Purnamasari, L. (2013). Pengaruh perubahan dividend payout ratio dan dividend yield terhadap return saham (Studi pada perusahaan manufaktur di Bursa Efek Indonesia). Journal of Business and Banking, 3(2), 213-222.

Putra, A. S. (2018). Anak muda miliarder saham. PT elex media komputindo. Gramedia. Jakarta

Suciati, N. H. D. (2018). The Effect of Financial Ratio and Firm Size on Stock Return in Property and Real Estate Companies Listed on the Indonesia Stock Exchange.

Tamunu, S. C., \& Rumokoy, F. (2016). The influence of fundamental factors on stock return (Case study: Company Listed in LQ45 2011-2014). Jurnal EMBA: Jurnal Riset Ekonomi, Manajemen, Bisnis dan Akuntansi, 3(4). Tandelilin, E. (2010). Portofolio dan Investasi, Edisi Pertama. Yogyakarta: Kanisius, 1(1). 


\section{Appendix}

\section{Return on Equity}

Return on Equity $=\frac{\text { Net Income }(\mathrm{NI})}{\text { Shareholder equity (E) }}$

\section{Dividend Yield}

Dividend Yield $=\frac{\text { Dividend per share }}{\text { Price per share }}$

Price Earning Ratio

Price Earning Ratio $=\frac{\text { Stock Price }}{\text { Earning per share }}$

\section{Earning per Share}

Earning per Share $=\frac{\text { Net Income }}{\text { The number of outstanding shares }}$

Firm Size

Firm Size $=$ Ln(Stock Price $\times$ Number of outstanding shares $)$

\section{Stock Return}

Stock Returns $=\frac{\left(\text { Price }_{t 1}-\text { Price }_{t-1}\right)-\text { dividend }}{\text { Price }_{t-1}}$ 